\title{
Finszter Géza
}

\section{A rejtőzködő bün és a büntető hatalom}

\author{
Hiding crime and punishing power
}

\begin{abstract}
Absztrakt
A múlt megismerése akkor kap eljárásjogi jelentőséget, amikor valamely megtörtént eseményhez jogkövetkezmények járulnak. A bünügyek mellett ezt láthatjuk a civiljogi perekben, a közigazgatási hatósági eljárásokban, de példák hozhatók a munkajog területéről is. Amennyiben a kriminalisztika a múltbeli esemény rekonstrukciójának a tudománya, akkor indokolt lehet annak kiterjesztése valamennyi jogterületre. Ilyen fordulat azonban nem következett be, a nyomozástan megmaradt bünügyi tudománynak. A cikk ennek a helyzetnek az okait kutatja.
\end{abstract}

Kulcsszavak: kriminalisztika, a múlt megismerése, büntetőeljárás

\begin{abstract}
Learning the past will acquire a procedural significance when some real event of the past would trigger legal consequences. In addition to criminal cases this can be realized in civil litigation, in administrative procedures of the public power, but examples can also be taken from the field of labour law. As criminalistics represent the science of reconstructing a past event, an extension of it to all legal fields can be reasoned. However, such a turn does not have taken place, the discipline of investigation remained within the sphere of criminal sciences. The article examines the causes of that.
\end{abstract}

Keywords: criminalistics, learning the past, criminal procedure

A bünügyek és a szabálysértések feltárásának mindig sajátos arculatot ad, és ezért a jogi megismerés más területeitől elkülöníti az a körülmény, amelynek az egyik oldalán találjuk a rejtőzködő jogsértést, a másik póluson pedig az 
állam impériumát, azt a büntető hatalmat, ami nélkülözhetetlen a társadalomvédelmi célok megvalósításához.

\section{A rejtőzködő bün}

A polgári eljárásokban is gyakori, hogy a peres igényt eldöntő tények megállapítása nehézségekbe ütközik, de kétségtelen, hogy ott számos körülmény segíti a jogvita megoldását. A felek a jogügyletet nem kívánják elrejteni. Írásos szerződést kötnek - az írásbeliség gyakran kötelező - magán- vagy közokiratba foglalják akaratukat, sokszor kötelező az ügyvédi közremüködés, tanúkat hívnak, illetve más módon gondoskodnak arról, hogy esetleges későbbi konfliktusaik rendezhetők legyenek. Ami nem jelenti sem azt, hogy az igény jogosságának megítélése kevéssé lenne bonyolult feladat, sem azt, hogy a valóság megállapítása minden peres fél érdekében állna. Ennek ellenére a felmerülő jogkérdések többsége a polgári igazságszolgáltatást megelőző hosszadalmas bizonyítási előkészítés nélkül is eldönthető. Ezzel szemben a jogsértések, és különösen a büncselekmények egy jelentős része tanult viselkedés, szükségletkielégítő magatartás, amelyben a tanulás a bün eltitkolásának technikáira is kiterjed. Racionalitását éppen az esély adja, amely szerint az elkövető elkerülheti a felelösségre vonást. Nem kevésbé nehezen felderíthetók azon irracionális, indulatoktól vezérelt deliktumok, amelyek esetében sem észszerüségről, sem tanulásról nem beszélhetünk, de éppen a spontaneitás állhat a sikeres bizonyítás útjában. A nyomozás mint megismerési folyamat, mint felderítés, mint a bizonyítékok felkutatásának professzionális taktikája és technikája e jellemzőkre adott válaszként alakult ki.

A kriminalisztikai módszertan terjeszkedésének egy másik irányára Petrétei Dávid hívja fel a figyelmet: „A XXI. századra elszakadt a büntetö eljárásjogtól, eszköztára bevethetö a magánnyomozásoktól kezdve a szabálysértési jogon át a munkabalesetek kivizsgálásáig nagyon sok területen. A megismerés eszköztára rohamosan fejlödik, a szak-természettudományok alapkutatásainak megfelelöen. A kriminalisztikai megismerési módszertan sok hasonlóságot mutat az orvosi diagnosztikával vagy akár a régészettel is." (Petrétei, 2018).

\section{Az állam büntető hatalma}

A magánjog az a terület, ahol a felek rendelkezési joga a legszélesebb, az állami beavatkozás pedig a lehető legszükebb körre szorítandó. Itt nem találkozunk 
azokkal a társadalomvédelmi követelményekkel, amelyek a közjogot jellemzik. A közjog részeként funkcionáló büntetőjognak viszont eminens feladata a közjavak védelme, amelyhez hatékony, és kizárólag az államot megillető eszközökre van szüksége. „, Az Alaptörvény és a jogszabályok érvényre juttatása érdekében kényszer alkalmazására az állam jogosult." (Alaptörvény C. cikk 3. bekezdés). Az állami kényszer egyik megjelenése az államigazgatási hatósági jogkörbe sorolható rendészeti kényszerintézkedés, aminek ultima ratioja a legitim fizikai erőszak monopóliuma. Ettől különböző az állam büntető hatalma, amit jól reprezentálnak a büntetés jogával szoros összefüggésben álló büntetöeljárási kényszerintézkedések, különösen azok, amelyek a személyes szabadság korlátozásával járnak. Utóbbiak eljárási oka az, hogy az igazság megállapítása során számos nehézség merülhet fel, a hatóság ismerethiányban szenved, az elkövető viszont információs monopólium birtokában van. Nem ritkán a maga teljességében csak ő hordozza azt a tudást, ami az általa elkövetett büncselekmény megismeréséhez szükséges. A büncselekmény előkészítése során, a véghezvitelkor és azt követően is lehetősége van arra, hogy a felelősségre vonást elkerülje vagy akadályozza, de arra is, hogy a megkezdett bünös úton továbbjárjon, vagy újabb büncselekmény megvalósításába fogjon. Alapvetően - más eljárásjogi célok mellett - ezeknek a veszélyeknek a korlátok közé szorítására szolgálnak a büntetőeljárási kényszerintézkedések. Alkalmazásuk törvényes feltételeinek kialakítása, és foganatosításuk normatív rendje a büntetőeljárás-jog kompetenciája. A kényszerintézkedések jogszerủ alkalmazása a múltra és a jelenre vonatkozó tények megismerését, illetve jövőbeni feltételek bekövetkezésének valószínúsítését igényli, és ehhez már a kriminalisztika által kidolgozott módszerekre van szükség.

\section{Szakmai tudás vagy tudományos ismeret}

A bün megismerése az igazságszolgáltatás számára történik, ezért a büntetőeljárás minden jogászi szakképesítésủ szereplöjétől elvárható a kriminalisztikai jártasság. A nyomozón kívül, munkája során az ügyész, a bíró és a védőügyvéd is kriminalisztikai problémák egész sorával szembesül. Ezek a kérdések az eljárás egyes alanyai számára eltérő módon merülnek fel, és eltérő válaszokat igényelnek. A kriminalisztikai felkészültség:

- a nyomozásban elsősorban a gyanú megfogalmazásához, a verziók felépítéséhez, a felderítés megtervezéséhez és a nyomok felkutatásához szükséges;

- az ügyészi szakban a vizsgálatnak, a vádemelésnek és a vádképviseletnek az egyik szakmai alapját alkotja; 
- feltétele a sikeres védelemnek;

- a tárgyaláson a bíró számára lehetővé teszi a bizonyításnak olyan szintézisét, ami nélkülözhetetlen a bizonyítékok mérlegeléséhez, és az erre alapított belső meggyőződés kialakításához, végső soron a bírósági döntés meghozatalához.

Mi tehát a kriminalisztika? Bünüldözési gyakorlat vagy tudomány? Mindkettő egyszerre!

A nyomozások a gyakorlati cselekvés színterei. A nyomozó hatóság nem laboratórium, hanem bünüldöző szerv, ahol naponta kell bünügyeket megoldani. Ebben a folyamatban nem tudományos igazságok, hanem történeti tényállások várnak feltárásra, a cél nem az elmélet gazdagítása, hanem az állam büntető igényének érvényesítése.

A nyomozási gyakorlat ugyanakkor tárgya és egyben felhasználója is a kriminalisztika tudományának. A praxis nyújtja a kriminalisztikai kutatások számára azt az empíriát, amelynek tanulmányozása révén megismerhetök annak törvényszerüségei. A kutatási eredmények visszakerülve ebbe a közegbe, a büntetőeljárás törvényes és eredményes müködését támogatják. Az előbbiekből következik, hogy a kriminalisztika fogalom három definíciót is elbír: elöször a bünüldöző hatóságok gyakorlati tevékenysége, másodszor a nyomok keletkezésének, felkutatásának és a büntetőeljárásban való felhasználásuknak törvényszerüségeit kutató bủnügyi tudomány, harmadszor az állam- és jogtudományi, valamint a rendészettudományi karokon oktatott tantárgy.

\section{A kriminalisztika fogalma}

A hazai kriminalisztikai szakirodalom egységes abban, hogy kiindulási pontként elfogadja Viski László meghatározását, amely az 1961-ben kiadott nyomozástani kézikönyv bevezetőjében olvasható:

„A kriminalisztika a büncselekmények nyomozásának, felderitésének tudománya. Célja, hogy a tételes jog által meghatározott keretekben olyan módszereket és eljárásokat dolgozzon ki, amelynek a segitségével a készülö büncselekmények leleplezhetök, megakadályozhatók, a már elkövetett büncselekmények felderithetök, elkövetöjük megállapitható és felelösségre vonható. A kriminalisztika tanulmányozza a nyomozás szolgálatában álló természettudományos, müszaki, technikai eszközök és eljárások egyes fajtáit, a nyomozási módszereket, a nyomozási cselekmények véghezvitele során célszerü eljárásmódot meghatározó elveket és szabályokat, végül az egyes büncselekmény fajták felderitésére 
alkalmas eszközök és módszerek célszerü és tervszerü felhasználásának kérdéseit. Ismeretanyaga egységes összefüggö egészet alkot, amelynek alkalmazása a büncselekmények felderitésének eredményesebbé tételével szolgálja a bünözés elleni küzdelem céljait.” (Kriminalisztika, 1961).

\section{Felderítés a büntetőeljáráson kívül}

Viski formulájának első mondata szerint a kriminalisztika tudományának tárgya a nyomozás, a felderítés. Szakirodalmi vita folyt arról, hogy miként értelmezhetők a nyomozás és a felderítés fogalmak (Borszéki \& Lakatos, 1999). Volt olyan időszak, amikor konszenzus alakult ki, miszerint a felderítés a nyomozás előtti, jog által nem szabályozott rendészeti intézkedések sora, amelynek fö célja a bünüldöző hatóságok információs szükségletének kielégítése. A büntetőeljárást megelőzően gyakorolt felderítés nem csupán a jogi szabályozást nélkülözte, hanem - föként a titkosság okán - a tudományos vizsgálódásoktól is elzárkózott. És valóban, a kriminalisztikai szakirodalomban múltjában sokáig hiába kerestünk volna a nyomozáson kívüli felderítés elméletét tárgyaló munkákat, ezeket az érintett bünüldöző szervek oktatási anyagai és belső hivatali dokumentumai helyettesítették. A nyomozás ellenben a büntetőeljárási jog által szabályozott bizonyítási cselekmények láncolata, ami már legalább százötven év óta, a tudományos igény diktálta kutatói érdeklődés tárgya. Lényegében ebből az igényből és érdeklődésből született meg a kriminalisztika.

\section{A kutatási tárgy szükebb és tágabb meghatározása}

A „Viski definíció” második mondata a kutatási tárgyat egyfelől szúkíti, amikor azt ,, a tételes jog által meghatározott keretekben” helyezi el, másfelől viszont bővíti is, amikor olyan eljárásokról és módszerekről szól, amelyek nem csupán a már elkövetett büncselekmény gondolati rekonstrukcióját teszik lehetővé, hanem alkalmasak a készülő büncselekmények leleplezésére és megakadályozására. Többen a kriminalisztika tárgyának tekintik azoknak a rendészeti beavatkozásoknak a taktikáját is, amelyek az elkövetők kézre kerítését, a bünös magatartás félbeszakítását és az elfogást szolgálják (Molnár, 1995). „Logikailag és történetileg is a büntetöeljárás a bünüldözéssel kezdödik, amelyben a büncselekmény felderitése, a bizonyitékok felkutatása, rögzitése, a feltételezett elkövetö felderitése és esetleges elfogása is beletartozik." (Király, 2000). 
A kutatási tárgy terjedelmének megállapítása nem független a büntetőeljárás egyes szakaszainak egymáshoz való viszonyától és a büntető igazságszolgáltatásban játszott szerepétől. A kriminalisztika tárgyának a nyomozásra szükítése nem jelentett veszteséget akkor, amikor a nyomozást a büntetőeljárás egyik főszakaszának tekintették, és jelentőségét azonosították a tárgyalással. Ez a szükítés azért sem okozott fejtörést, mert a vádemelés és a bírósági tárgyalás a feltárt tényállás jogi értékelésének mutatkozott, ami már nem kriminalisztikai, hanem büntető anyagi és eljárásjogi feladvány, mondhatjuk úgy is, hogy jogalkalmazói teljesítmény.

Volt egy viszonylag rövid időszak, amelyben kísérlet történt az eljárási szakaszok átértelmezésére. Eszerint az igazságszolgáltatást előkészítő nyomozás nem lehet egyenrangú a tárgyalással, és nem is várható el attól olyan eredmény - a tényállás minden részletében való és teljes bizonyosság erejével történő feltárása -, amely csak a bírósági ítéletnek lehetnek a tulajdonságai. Ezzel összefügg az a kérdés is, hogy ami a nyomozásban megvalósul, az vajon bizonyításnak tekinthetö-e, avagy ott csupán a bizonyítási eszközök felderítése, rögzítése és a további eljárás számára való biztosítása történik. A szűkebb értelemben felfogott bizonyítás a tárgyaláson történik, vélték többen. Ezt a konstrukciót a szakemberek egy része kritikával illette (Katona, 2004). Részben az ellenvetések hatására visszatértünk ahhoz a korábbi felfogáshoz, miszerint az eljárás előkészítésekor a tárgyalással azonos jelentőségü bizonyítás folyik. Eszerint a bíróságnak nincs kitüntetett szerepe, sőt, ha azt is számításba vesszük, hogy a hatályos szabályozás milyen széles körben teszi lehetővé a büntető felelősség megállapítását tárgyalás nélkül, akkor még inkább szembesülhetünk az előkészítő szakasz felértékelődésével. A nyomozás felderítésre és vizsgálatra bontása lényegében megfelel annak a már idézett tankönyvi álláspontnak, miszerint a felderítés a nyomozásnak az a szakasza, amelynek célja az ismeretlen elkövető személyének megállapítása, felkutatása és kézre kerítése (Borszéki \& Lakatos, 1999). Ehhez képest a vizsgálat az ügyészség döntésének megalapozása a gyanúsított elleni eljárás befejezéséről.

Az elöbbiek alkalmat adhatnak a kriminalisztika tárgyával kapcsolatban néhány következtetés levonására.

- A kriminalisztika megmaradt a nyomozás tudományos eszközökkel kidolgozott tanának. A vádemelésnek és a bírósági tárgyalásnak nincs önálló kriminalisztikája. Indokolt viszont a büntető igazságszolgáltatás szakembereinek kriminalisztikai ismereteit tovább gyarapítani.

- A kriminalisztika feladata a bünüldözés teljes folyamatának (előkészítő eljárás, nyomozás) tanulmányozása abból a célból, hogy az valóban a hatékony bünüldözést szolgálja, és ne válhasson az emberi jogok önkényes 
korlátozásának eszközévé. Ennek azonban az a feltétele, hogy a leplezett eszközökkel folytatott titkos felderítés teljes terjedelmében a büntetőeljárási jogban kerüljön szabályozásra. Ezt a feltételt a hatályos büntetőeljárási törvény teljesítette. „A leplezett eszközök alkalmazása olyan, a magánlakás sérthetetlenségéhez, valamint a magántitok, a levéltitok és a személyes adatok védelméhez füzödö alapvetö jogok korlátozásával járó, a büntetőeljárásban végzett különleges tevékenység, amelyet az erre feljogositott szervek az érintett tudta nélkül végeznek." [A büntetőeljárásról szóló 2017. évi XC. törvény 214. § (1) bekezdése].

- A kriminalisztika kutatási tárgyát bővíteni szükséges a bünüldözés tárgyi és személyi feltételeinek vizsgálatával. A büntető igazságszolgáltatás szervezeti kérdései ugyancsak elméleti alapokat kívánnak, ezek kimunkálása azonban inkább a büntetőeljárási jog tudományának lehet a feladata.

Az elöbbiekben felsorakoztatott követelmények a kriminalisztika tudomány jövőbeni fejlesztésének irányait rajzolja meg. Ezek szerint meg kell őriznie alapvető küldetését, az egyes büncselekmények nyomozásának taktikai és technikai eszköztárának kritikai elemzését és fejlesztését. Emellett a leplezett eszközöknek az előkészítő eljárásban és a nyomozásban történő alkalmazása ugyancsak kriminalisztikai módszerekkel történő feltárásra vár. Végül feladata a bünözéssel mint tömegjelenséggel szemben felépített bünüldözési szervezet legcélszerübb kialakításának és működtetésének a támogatása a maga tudományos eszközeivel.

\section{A hagyományos és a stratégiai kriminalisztika}

A hagyományos kriminalisztikai gondolkodás, amelynek forrásvidéke a 19. század európai polgárosodásában található, az egyedi bünesetek megoldására koncentrált, és nem tekintette feladatának a bünözés átfogó tanulmányozását, amit meghagyott az ugyanabban az időben születő kriminológiának. Ez a képlet emlékeztet a detektív történetek szerkezetére, amelyben egy elkövetett büncselekménnyel szemben áll egy (rendszerint zseniális) nyomozó. A valóságban azonban a bünügyi rendőrségeknek, a bünüldöző hatóságoknak mindig a bekövetkezett büncselekmények tömegével kellett szembe nézniük, amihez a kriminológiának nem volt sok szava, mert annak figyelmét a jövőben fenyegető bünök megelőzése kötötte le. Különösen a bünözés 20. században megfigyelt növekedése, és a bünüldözés eredményességének hanyatlása sürgette bünüldözési stratégiák kialakítását, olyan szervezeti, jogi és müködési feltételek folyamatos és tervszerü biztosítását, ami nem csupán egyetlen deliktumra figyel, 
hanem a bünözés teljes terjedelmével szemben kíván hatékony megoldásokat. Erre a feladatra vállalkozik a stratégiai kriminalisztika. A bünüldözési stratégia jelentőségére először Szabó András hívta fel a figyelmet egy 1988-ban a Belügyi Szemlében publikált tanulmányában (Szabó, 1988).

A stratégiai kriminalisztika egyik új iránya a kriminalisztikai logisztika, amely a sikeres bünüldözéshez szükséges tárgyi feltételek folyamatos biztosításának feltételeit tanulmányozza. Déri Pál a korszerü nyomozásról és az integrált bünüldözésről írt tanulmányában részletesen bemutatja azokat a krimináltaktikai megfontolásokat, amelyek eredményeként elérhető, hogy a felderítő beavatkozás az elkövetés helyéhez legközelebb, az elkövetés idöpontjához képest a legkevesebb időveszteséggel történjék, mégpedig olyan módon, hogy a bünüldözés a legmagasabb szakértelmet és technikai készültséget mozgósítsa (Déri, 2004). A kriminalisztikai menedzsmentnek arra kell törekednie, hogy adottak legyenek a személyi feltételeket. Ahhoz, hogy ezek a képességek sikerre vezessenek, szükséges felhasználni a kriminalisztikai informatika új lehetőségeit, különösen a számítógépes automatizált szakértői rendszereket és az ezekhez társuló korszerü nyilvántartásokat (Déri \& Budai, 1991).

A rendőri megelőzés túlsúlyba kerülése a represszióval szemben egy olyan átfogó kriminálstratégia megalapozásához vezethet, ami képes létrehozni a ,bünfelderités és a megelözés egységes rendszerét" (Kube \& Simmross, 2002).

\section{A rendészeti és a büntetőeljárási kényszer}

Ami a büncselekményt megszakító és az elkövetők elfogására irányuló rendészeti beavatkozások kriminalisztikai vizsgálatát illeti, azt kell megállapítanunk, hogy a legitim eröszaknak ezek a formái eddig nem kerültek tanulmányozásra, a krimináltaktikai kézikönyvekben még utalás sincs rájuk. A hiány egyik oka, hogy a rendészeti kényszerintézkedések kívül esnek a büntetőeljárási szabályozás körén, a másik ok pedig az lehet, hogy a büntetőeljárási kényszerintézkedésekre a tudomány hagyományosan nem megismerési, hanem kizárólag szabályozási problémaként tekintett, ami az eljárási dogmatika hatáskörét indokolja.

A kényszerintézkedéseknek két formáját kell megkülönböztetni.

- A rendészeti kényszer nem az eljárási törvényekben, hanem rendszerint a rendvédelmi szervek szervezeti törvényeiben kap szabályozást, végrehajtása sem csupán a nyomozó hatóságok, hanem közrendvédelmi és különleges rendőrségi szolgálatok, valamint más rendvédelmi és nemzetbiztonsági szervek feladata, teljesítése speciális készségeket, képességeket és jártasságot 
követel. A legitim fizikai erőszak szükséges és arányos alkalmazásának fogásai a kiképzés során sajátíthatók el, törvényszerüségeit nem a kriminalisztika, hanem a rendészettudomány tanulmányozza. A rendészeti kényszer célja a jogsértésből keletkező veszélyek elhárítása vagy csökkentése.

- A büntetőeljárási kényszerintézkedéseket az eljárási törvények szabályozzák, végrehajtásukra kizárólag nyomozó hatóságok jogosultak, alkalmazásuk normatív rendjének dogmatikája a büntetőeljárási jog tudományának hatókörébe illeszkedik, ellenben gyakorlati alkalmazásukhoz a kriminalisztika dolgoz ki ajánlásokat. A büntetőeljárási kényszerintézkedéseknek csak eljárási okai lehetnek, végső soron céljuk az állam büntető igényének érvényesítése a büntető igazságszolgáltatás útján.

Az előbbiek tisztázását követően pontosítható a kriminalisztika kutatási tárgyának meghatározása. A kriminalisztika önálló kutatási tárgya ezek szerint a büntetőeljárási jog által szabályozott, és a védelem kontrollja alatt álló ismeretszerzés az igazságszolgáltatás számára arról, hogy történt-e büncselekmény, és annak ki az elkövetője. Mindennek legitim célja az, hogy az állami büntető igény az igazságszolgáltatás útján törvényesen és eredményesen érvényesíthető legyen.

\section{Felderítés és bizonyítás az I. Be. idején}

Amikor Viski László felderítésről szól, akkor azt a nyomozással szinonim fogalomként használja, a kriminalisztika tárgya tehát nem a büntetőeljárást megelöző, hanem a nyomozásban teljesített felderítés. Ez az értelmezés felelt meg az 1973. évi I. törvénnyel kihirdetett büntetőeljárási kódex (továbbiakban I. Be.) szemléletmódjának.

Az I. Be. két rendelkezése különösen igényli a kriminalisztikai értelmezést.

- Elöször figyelmet érdemel, hogy az I. Be. valamennyi eljáró hatóság kötelességévé tette a tényállás valóságnak megfelelő alapos és hiánytalan tisztázását az eljárás minden szakaszában. További fontos konklúzió, hogy az eljárási szakaszok a múlt feltárásában azonos jelentőséggel bírtak, ebből a bírósági tárgyalás sem emelkedett ki. Minden szakaszban az igazságot kellett megállapítani, és valamennyi eljáró hatóság a tényállás megállapítására alkalmas bizonyítékokat meggyőződés alapján bírálta el.

- Másodszor garanciális tartalmú rendelkezés volt, miszerint büntetőeljárást csak büncselekmény alapos gyanúja esetén és csak az ellen lehetett indítani, akit büncselekmény alapos gyanúja terhelt. A gyanú fokozatairól szóló 
szakirodalom sejteni engedte, hogy az alapos gyanúig vezető úton is folyhat felderítés, de ez sokáig nem került törvényi szabályozásra, és nem is lehetett a kriminalisztikai kutatások tárgya sem.

Az előbbiekben vázolt eljárási filozófiát a büntetőeljárásról szóló 1998. évi XIX. törvény (továbbiakban II. Be.) több ponton lényeges átalakította.

\section{Felderítés és bizonyítás a II. Be. idején}

A II. Be szerint a nyomozás olyan előkészítő eljárássá vált, amelynek rendeltetése az adatszerző felderítés a bírósági tárgyaláson megvalósuló bizonyítás megalapozásához. Ebből a szempontból a nyomozás nem egyenrangú, hanem alárendelt a bírósági szakasznak, de nem is feladata a tényállás alapos és hiánytalan megállapítása. A nyomozási döntések forrása a hierarchiából fakadó rend és nem a belső meggyőződés. (Ilyen meggyőződés csak személytől és nem szervezettől várható.) Az igazságszolgáltatási cél primátusa indokolta azt is, hogy az ügyész a teljes nyomozás felett rendelkezési jogot kapott. E jog gyakorlása során, valamint a vádemelésben és a vádképviseletben a II. Be ügyészi autonómiát feltételezett, ami akkor teljesül, ha az ügyész döntéseit - a bíróhoz hasonlóan - személyesen, belső meggyőződésére alapítva hozza meg.

A II. Be reform értékủ változásokat hozott, amelyeket azonban sem a bünüldöző sem az igazságszolgáltatási szervek nem fogadtak be, minthogy szervezeti reformok nélkül erre nem voltak felkészülve. A kriminalisztika fejlődése szempontjából lényeges felismerés, hogy a felderítésre koncentráló nyomozásnak nem a bírósági tárgyalással kellett volna versenyre kelnie, hanem a kriminalisztikai jártasságával emelhette volna tekintélyét, amit az ügyész széles körü rendelkezési joga sem csorbíthat. Ez a szemléletváltás azonban nem következett be, a jogalkotás pedig új irányt választott. A rövid életű II. Be. helyébe 2018. július 1-jei hatállyal a büntetőeljárásról szóló 2017. évi XC. törvény (továbbiakban III. Be) lépett.

\section{Felderítés és bizonyítás a III. Be. idején}

A hatályos III. Be. szakított azzal a törekvéssel, ami az előkészítő eljárástól nem bizonyítást, hanem csupán az ahhoz szükséges információk megszerzését várta el. A nyomozás ebből a szempontból ismét egyenértékü lett a bírósági tárgyalással, mint előzetes, de mégis teljes bizonyítás felvételi eljárás. 
A III. Be. kommentárja kiemeli: „A nyomozás lényegét tekintve, a bizonyitási eszközöket összegyüjtö és rögzitö, a bizonyitási eljárások eredményét megállapitó, valamint mindezeket az ügyészség és a nyomozó hatóság által értékelö [...] elözetes bizonyitás felvételi eljárás” (Belegi, 2018).

A nyomozástól a törvény nem kívánja meg a tényállás hiánytalan megállapítását, de azt igen, hogy a bíróság, az ügyészség és a nyomozó hatóság a bizonyítékokat egyenként és összességükben szabadon értékelje, a bizonyítás eredményét az így kialakult meggyőződése szerint állapítsa meg. Ez a meggyőződés azonban nem személyes, hanem a szervezet müködésének az eredménye.

A törvény arról sem szól, hogy milyen feltétele van a nyomozás megkezdésének. Csupán azt olvashatjuk a 348. § (1) bekezdésében, hogy a büntetőeljárás - ha a törvény kivételt nem tesz - nyomozással kezdődik. Ilyen kivétel az előkészítő eljárás.

Azt, hogy a nyomozó hatóság büncselekmény gyanúja alapján indít nyomozást, csak a nyomozás és az előkészítő eljárás részletes szabályairól szóló kormányrendeletből tudjuk meg [100/2018. (VI. 8.) Korm. rendelet 122. §]. A nyomozás megkezdéséhez olyan információkra van szükség, amelyekből legalább két következtetés levonható.

- Elöször az, hogy indokolt előkészítő eljárás lefolytatása, mert az nélkülözhetetlen a büncselekmény gyanújának megállapításához, az előkészítő eljárás törvényi előfeltételei adottak, és az eredményes előkészítő eljárás nyomán a büncselekmény gyanúja megállapítható.

- Másodszor az, hogy nem indokolt előkészítő eljárás, mert a hatóság hivatalos tudomása vagy a feljelentés alapján rendelkezésére állnak olyan adatok, amelyekből a büncselekmény gyanúja, mint a nyomozás megkezdésének szükséges és elégséges feltétele, megállapítható.

A III. Be. a felderítésnek normatív tartalmat adott (eljárásjogi intézménnyé tette), amikor megállapította, hogy a nyomozás felderítésből és vizsgálatból áll. A felderítésnek feladatul szabta, hogy a megalapozott gyanú megállapításához szükséges mértékben fel kell deríteni a büncselekményt és az elkövető személyét. A nyomozó hatóság az előkészítő eljárás és a felderítés során önállóan, a vizsgálat során az ügyészség irányításával jár el. Ez azt jelenti, hogy megszünt az ügyész általános rendelkezési joga, amit a II. Be. még hangsúlyozott. Az idézett kommentátor szerint: „, A nyomozás két szakasza közötti különbséget nem annyira a tényleges tevékenységben, inkább a nyomozó hatóság és az ügyészség közötti kompetenciaelosztásban látom...", majd rámutatva arra, hogy az ügyészség, mint közvádló az állam büntető igényének kizárólagos érvényesítője, így folytatja: 
„Mindebböl az is következik, hogy a nyomozást befejezö döntésért az ügyészség osztatlan felelösséggel tartozik, amely akkor lehet valóságos, ha a nyomozás egésze fölött rendelkezési, döntési jogosultsága van." (Belegi, 2018). A tényleges jogi helyzet azonban mégis az, hogy az ügyész rendelkezési joga a vizsgálatra szükült, ott viszont maradéktalan, amikor az ügyész dönt a gyanúsítottal szemben folyamatban lévő nyomozás befejezéséről. A nyomozást az eljárás megszüntetése vagy a vádemelés fejezi be.

\section{A kriminalisztika tárgya a hatályos eljárási törvény (III. Be.) szerint}

A kriminalisztika a tételes jog keretei között kerül művelésre, ezért a hatályos törvény jelöli ki annak kutatási tárgyát, ami magába foglalja az előkészítő eljárást, valamint a felderítésre és vizsgálatra tagozódó nyomozást. Az eljárás ilyen szakaszolása kihívást jelent a nyomozástan számára. Természetesen a tudománynak nem az a feladata, hogy igazolja a tételes jogi megoldás helyességét, hanem az, hogy adja annak tudományos igényü kritikáját, segítve az eredményes és törvényes bünüldözést és igazságszolgáltatást.

\section{A kriminalisztika kompetencia alapú rendszere}

A kompetencia alatt ebben az esetben a nyomozó hatóságok anyagi-technikai felszereltségét, és tagjainak szakmai felkészültségét értjük. A kriminalisztika a 19. század végén az osztrák Hans Gross és a francia Edmond Locard munkássága révén született szakkifejezés, ami eredetileg a bünügyi nyomozó speciális szaktudását kitöltő gyakorlati ismeretek együttesének a megjelölésére szolgált (Margot, 1999). Ehhez képest a kriminalista (ahogy nálunk sokáig nevezték, a detektív, vagyis a tények feltárója) olyan különleges ismeretek birtokosa, aki az ilyen tudást igénylő szakkérdések megválaszolásával segíti a nyomozást. A különleges szakértelem alsó határát a kriminalisztikai szaktudás jelenti. Szakértőre akkor van szükség a nyomozásban, ha a szakkérdés eldöntéséhez a nyomozó (bünügyi technikus) szaktudása sem elegendő (Erdei, 1987). A kriminalisztikai tudásanyag rendszerezése és elméleti megalapozása, valamint új ajánlások kimunkálása a krimináltaktika, a kriminalisztika egyik ágának a feladata lett. A „tudományos rendőrség” a 20. század elején kifejlesztett rendörségi azonosító laboratóriumok múködésének megjelölésére szolgált, minthogy ezekben az intézetekben a kémia, a biológia, a fizika, az orvostudományok és 
más természettudományok képviselői, e tudományterületek által feltárt eszközök és módszerek segítségével igyekeztek segítséget nyújtani a tárgyi bizonyítékok felkutatásához, a múltbeli esemény rekonstruálásához, valamint az ehhez szükséges azonosítási müveletek elvégzéséhez. A laboratóriumi háttér megkívánta a helyszínen folytatott nyomkutató és nyomrögzítő feladatok technikailag magas színvonalú elvégzését, ami a bünügyi nyomozó mellett újabb szakember, a bünügyi technikus tudásának a törzsét alkotta. Ezek az ismeretek a krimináltechnikában integrálódtak. A laboratóriumi szakértő és a bünügyi technikus bizonyítási tevékenységének próbáját jelentette, hogy megállapításaik és az általuk feltárt tárgyi bizonyítékok mennyire alkalmasak a büntető perben az itélethez szükséges belső meggyőződés kialakítására.

A kontinentális tárgyalási rendszer, ami inkább tekinthető a nyomozási anyag felmondásának, mint a tényállás megállapításához szükséges eredeti bizonyítás felvételének, a bünügyi nyomozóknak és a bünügyi technikusoknak a bíróság előtti szereplését a minimumra szorította, és ha az mégis bekövetkezett, a nyomozó kihallgatása inkább hasonlított „társhatóságok” közötti disputához, mint ügyféli közremüködéshez. Az angolszász rendszerü büntető perben azonban az érdemi bizonyítás a tárgyaláson történik, ezért itt döntő jelentősége van annak, hogy a bünügyi nyomozás anyagának felkutatásában részt vett detektívek és bünügyi technikusok miként képesek érveiket a bíróság elé tárni. A laikus esküdtek számára bonyolult szakértői eljárásokat közérthető módon bemutatni, ez lett az egyik legfontosabb szakértői képesség. Csak az ilyen módon felvett bizonyítás teszi lehetővé a védelem számára az egyes bizonyítékok hitelt érdemlőségének ellenőrzését, és csak ennek révén lehetséges eljutni a kétségeket kizáró bizonyosságig. Az angolszász jogrendszer országaiban a kriminalisztikai szakismeret lényegét ennek a véleményformálásnak, valamint a vélemény igazságügyi fórumok elé terjesztésének a módszertana alkotta. Ezt a tudásanyagot nevezték forenzikus tudománynak (forensic science). Más értelmezés szerint a forenzikus tudományok körét az igazságügyi orvostan, a vegytan, a fizika és további olyan természettudományos háttérre támaszkodó igazságügyi tudomány képezi, amelyeknek közös ismérve, hogy saját szakterületük ismereteit, eljárásait, technikáit és módszereit a jogi eljárásokban felmerülő, különleges szakértelmet kívánó kérdések megválaszolásának szolgálatába állítják. Ebben a csoportosításban a kriminalisztika feladata , a forenzikus tudományok számára egy általános elmélet és metodológia” kidolgozása (Katona, 2002).

$\mathrm{Az}$ angol kifejezés, a forensic science szinte teljesen lefedi a kontinentális krimináltechnika fogalmát. Azonban a két eljárási rendszer konvergenciája a kriminalisztika szemantikájában is felismerhető. Katona Géza megállapítja, hogy a kriminalisztika kifejezés (és az ehhez kapcsolódó nyomozástani szemlélet) egyre 
inkább terjed az angolszász jogi kultúrában is. A már idézett Pierre Margot arra hívja fel a figyelmet, hogy a kontinentális gondolkodás viszont egyre nagyobb érdeklődést mutat a forenzikus tanítások iránt, olyannyira, hogy francia nyelvterületen terjedőben van az angol kifejezés megfelelöje a „sciences judiciaires” (Margot, 1999). Sőt, a kriminalisztika művelésében hírnevet szerzett lausanne-i egyetem „,neológusai” már megalkották a francia „sciences forensiques” kifejezést. Mindez nem csupán játék a szavakkal, hanem egyértelmü szemléletváltás. Az előkészítő szakaszt a következetes vádelv szeretné a laikus polgár akciójának láttatni, amellyel bíróság elé viszi a büncselekmény okozta sérelmet. Ez olyan fikció, ami nem tartható fenn. A büncselekmény gyanújának felmerülésétől kezdődően jelen van a hatóság a maga represszív felhatalmazásaival, amelyek ahhoz szükségesek, hogy az eljárás sikerét a büntetést kerülni kívánó érdekek ne veszélyeztethessék. De ugyanez a hatóság rendelkezik kriminalisztikai hozzáértéssel is, ami esélyt ad a múltbeli tényállás valósággal egyező megismerésének. A bünüldöző szervezet tagjával szemben támasztott szakmai követelmények elméletileg is megalapozott rendszerezett kifejtésének szüksége teszi mind népszerübbé a tengeren túl is a kriminalisztikai szemléletet, amelynek a bölcsője mégis csak a kontinentális inkvizíciós eljárási forma. Más oldalról viszont a tárgyalás felértékelődése a tényállás bizonyításában arra készteti a francia eljárási rendszeren nevelkedett bünügyi tisztviselőket, hogy képesek legyenek az általuk feltárt bizonyítékok hitelét a védelem érveivel szemben, egy kontradiktórius perben igazolni. Ez a forenzikus logika jellegzetes szereposztása. A kriminalisztika tehát eredetileg úgy alakult ki, mint a bünüldöző apparátusok gyakorlati tapasztalatainak az összegzése, amely egyúttal a bünügyi nyomozótól elvárható nélkülözhetetlen szaktudás, gondolkodásmód és cselekvési készség együttesét jelentette. Ez a tudásanyag szervesen beépül a kriminalisztika tudományos rendszerébe.

\section{Az igazságszolgáltatás szélesebb fogalma}

A hatályos büntetőeljárási törvény újra teret ad az igazságszolgáltatás egy szélesebb fogalmának, amelyben a bünüldözés egész apparátusa igazságszolgáltatási szerepet kap. „Az igazságszolgáltatás, vagyis a büntető igazságszolgáltatás tágabb értelemben magában foglalja az egész büntetöeljárást, valamennyi eljárásban közremüködö vagy részt vevö szerv és személy tevékenységét, és a közöttük keletkezö és fennálló valamennyi eljárási jogi kapcsolatot, vagyis jogviszonyt." (Büntetőeljárási jog, 1974). Nem állnak messze ettől a felfogástól az igazságügyi politikáról szóló 1710/2014 (XII. 5.) Korm. határozat következő iránymutatásai: 
„... a tágabb értelemben vett igazságszolgáltatásba vetett közbizalom erösödjön,

[...] az Alaptörvényben meghatározott tisztességes eljárás követelménye ne csak az eljárás tisztességére, nyilvánosságára és ésszerü határidejére vonatkozzon, hanem abból a döntés tisztességére vonatkozó elvárás megkérdöjelezhetetlen legyen,

e) szükséges a jogászképzés szinvonalának emelése, a jogászi hivatás védelme és a jogászi identitástudat növelése,

f) erösiteni kell az európai együttmüködés keretén belül a nemzeti érdek hatékony képviseletét,

g) elö kell segiteni az igazságügyi szervezetrendszerrel történö hatékony közremüködést és a velük történö kapcsolattartás folyamatos biztositását."

Az igazságügyi politikának helyes törekvése a döntések tisztességére vonatkozó elvárás megkérdőjelezhetetlensége, de ez a követelmény kizárólag a törvényesség maradéktalan betartása, a hatalmi ágak világos elválasztása, a bíróság függetlenségének érvényesítése mellett valósulhat meg, parancsba nem adható, meg kell érte dolgozni! Az alkotmányos jogállam alapértékei melletti elkötelezettség szolgálhatja a leghatékonyabban a jogászi hivatás védelmét és a nemzeti érdek hatékony képviseletét is. Az nem derül ki, hogy a határozat mit ért a kapcsolattartás folyamatos biztosításán. Az így keletkezett homályt talán az oszlathatja el a legjobban, ha a múltból (és nem a jogállami múltból) visszahozott szélesebb értelemben felfogott igazságszolgáltatás szemléletének veszélyeire hívjuk fel a figyelmet. A hatalmi koncentráció a végrehajtó hatalmat kivételes helyzetbe hozza - hiszen a parancs hatálya alá vont teljes bünüldözési apparátus a rendelkezésére áll -, ugyanakkor a bíróságot megfosztja attól a lehetőségtől, hogy ennek az előkészítő szakasznak hatékony kontrollját elvégezhesse. Nem árt figyelmeztetni arra, hogy a koncepciós perek „forgatókönyvei” az előkészítő eljárásban íródtak. Az igazságszolgáltatási szervek semmiféle kontrollt nem gyakorolhattak az ilyen nyomozások felett. Joggal állapította meg egy, a korszakról szóló tanulmány: „,... a tényállás koholtsága a jogi megitélésen kivül, a jog által ellenörizhetetlen szférában áll össze" (Szabó, 1975). A szélesebb értelemben felfogott igazságszolgáltatás ideológiája ezeket a veszélyeket hordozza. Erre figyelmeztet Bócz Endre tanulmánya: ,Igyekeztem kimutatni, hogy a »szükebb«és »tágabb« értelemben vett igazságszolgáltatás - eredetileg néhai Barna Péter nevével fémjelezhetö - koncepciója, amely szerint a nyomozásban 'a lényeget tekintve ugyanolyan bizonyitás folyik, mint a tárgyaláson', $s$ amely tudat alatt sok tekintetben még ma is meghatározza a jogalkalmazói szemléletet, nem állja meg a helyét. A bünözés, és - következésként - a bünüldözés sokat változott, de nem annyit, hogy a büntetö igazságszolgáltatás olyan 
kipróbált és bevált hagyományos elveit, mint a közvetlenség és a kontradiktórius tárgyalás, fel kellene adni" (Bócz, 2019).

Alkotmányos jogállamban a kormányzat számára az igazságszolgáltatással való „kapcsolattartás folyamatos biztosításának” egyetlen járható útja az igazságszolgáltatás fogalmának a bírósági ítélkezésre szorítása, és a bírói hatalmi ág függetlenségének megóvása.

„Pontosabban a hatalommegosztás célja és értelme az állampolgári szabadság biztositása: a törvényhozás, a végrehajtás és az igazságszolgáltatás elválasztása ugyanis azt a célt szolgálja, hogy ne jöhessen létre zsarnokság és önkény. Másrészt a hatalommegosztásban az a fajta etikai-morális felfogás fejezödik ki, amit ugyancsak Harrington mutat be a két lánynak a példáján, akik úgy osztoznak egy kalácson, hogy az egyikük kettévágja azt, a másik pedig választ a két darab közül." (Sári, 1995).

A büntetőeljárás előkészítése része a rendészeti müködésnek, a munkamegosztás rendjén azonban jogilag és szervezetileg is elkülönül egymástól a rendet óvó és az azonnali beavatkozásra felesküdött közbiztonsági rendőrség, valamint a ,jogrend helyreállitásában segédkezö biztonsági rendőrség” (Concha, 1905). Amit Concha Győző segédkezésnek nevez, azt az újabb irodalom az igazságszolgáltatás, a büntető per előkészítésének mondja. További elválasztó ismérv, hogy „, ... a bünüldözés nem a társadalmi rendet biztositja, hanem a büntetést”, s Concha jelzi azt is, hogy „, a jog uralma, amelyet végsö soron a bíróság tart fenn, adja az egyénnek valamint az államhatalomnak azt az érzést, amelyet biztonságnak nevezünk" (Concha, 1905). Ebben az esetben arról a biztonságról van szó, amelyben az állam nyugodt lehet afelöl, hogy az általa megalkotott törvényeknek érvényt fognak szerezni, az egyén pedig biztos lehet abban, hogy a független bíróság az államhatalom önkényétől is képes lesz megvédelmezni őt. Az elöbbiekböl az következhet, hogy a végrehajtó hatalomnak nem az igazságszolgáltatás környékén célszerü „tágítani” hatalmát, hanem a közbiztonság fenntartásában viselt felelősségét - a társadalommal és a rendészeti szakértelemmel összefogva - tervező munkával kellene megalapozni.

\section{Felhasznált irodalom}

Belegi J. (Szerk.) (2018). Büntetőeljárási jog I-II. Kommentár a gyakorlat számára. HVGORAC, Lap- és Könyvkiadó Kft.

Bócz E. (2019). Gyüjteményes kötet Bócz Endre irásaiból. Magyar Közlöny Könyv- és Lapkiadó Kft.

Borszéki Gy. \& Lakatos J. (Szerk.) (1999). Bevezetés a kriminalisztikába. Rejtjel Kiadó. 
Büntetőeljárási jog (1974). BM Tanulmányi és Propaganda Csoportfőnökség.

Concha Gy. (1905). Politika, Közigazgatástan. Budapest.

Déri P. \& Budai A. (1991). Korszerü bünüldözés. Országos Rendőr-fökapitányság.

Déri P. (2004). Az állam és a társadalom kötelezettségei a bünözés elleni harcba, Kriminalisztika II. Duna Palota és Kiadó.

Erdei Á. (1987). Tény és jog a szakvéleményben. Közgazdasági és Jogi Könyvkiadó.

Katona G. (2002). A kriminalisztika és a bünügyi tudományok. BM Kiadó.

Katona G. (2004). A bizonyítás és a nyomozás egyes kérdései az új Be tükrében. Magyar Jog, 51(9), 525-534.

Kertész I. (1972). A tárgyi bizonyitékok elmélete a büntetőeljárási jog és a kriminalisztika tudományában. Közgazdasági és Jogi Könyvkiadó.

Király T. (2000). Büntetőeljárási jog. Osiris Kiadó.

Kriminalisztika (1961). Belügyminisztérium Tanulmányi és Módszertani Osztály.

Kube, E. \& Simmross, U. (2002). Új fejlödési tendenciák a kriminalisztikában. A kriminalisztika aktuális kérdései. BM Kiadó.

Margot, P. (1999). Un changement de nom dans la continuité. Revue Internationale de Criminologie et de police technique et scientifique, 52(6), 6-8.

Molnár J. (1995). A kriminalisztika tudománya. Kriminológiai és Kriminalisztikai Évkönyv. IKVA Könyvkiadó.

Petrétei D. (2018). A bünügyi helyszín a szabványosítási tendenciák és az új Be. tükrében. Rendörségi Tanulmányok, 1(3), 4-48.

Sári J. (1995). A hatalommegosztás. Osiris Kiadó.

Szabó A. (1975). A jogászság megváltozott társadalmi szerepe. Szociológia, 4, 502-511.

Szabó A. (1988). Bünüldözési stratégiák. Belügyi Szemle, 26(12), 3-8.

\section{Alkalmazott jogszabályok}

Magyarország Alaptörvénye (2011. április 25.)

1973. évi I. törvény a büntetőeljárásról (I. Be)

1998. évi XIX. törvény a büntetőeljárásról (II. Be)

2017. XC. törvény a büntetőeljárásról (III. Be)

100/2018. (VI. 8.) Korm. rendelet a nyomozás és az előkészítő eljárás részletes szabályairól

1710/2014 (XII. 5.) Korm. határozat az igazságügyi politikáról

\section{A cikk APA szabály szerinti hivatkozása}

Finszter G. (2021). A rejtőzködő bűn és a büntető hatalom. Belügyi Szemle, 69(10), 1691-1707. https://doi.org/10.38146/BSZ.2021.10.1 